[22] Shchedrova H. P. Hromadianske suspilstvo yak peredumova stvorennia dynamichnoi politychnoi systemy. Politychna systema suchasnoi Ukrainy: osoblyvosti stanovlennia, tendentsii rozvytku / redkol. : F. F. Rudych (holova) ta in. Kyiv, 1998.

МАРТИРОСЯН Е. И., ПОРОШИНА В.Д., КУПРИЙ Т. Г. Украинское государство в современном геополитическом пространстве: национальная безопасность и проблемы единства.

На основании историко-политологических источников и исторических фактов в статье проанализированы этапы перестройки и реформащии украинского государства в современном геополитическом пространстве.

Анализируя дефиниции и определения исследователей разных исторических периодов, авторы пришли к заключению, что стратегическая и современная цель нашего государства состоит в сохранении грании и суверенитета и в дальнеймей интеграции к европейским и евроатлантическим структурам.

Именно вхождение Украины в европейский союз будет гарантией для построения правового государства и утверждения национальной независимости.

Ключевые слова: европейские государства, научный потенціал, стратегия образования, геополитическое пространство, правовое государство.

Martyrosian E. I., Poroshyna V. D., Kupryi T. H. The Ukrainian state is in modern geopolitical space: national safety and problems of unity.

On the basis of political историко-политологических sources and historical facts in the article the stages of alteration and reformation of the Ukrainian state are analysed in modern geopolitical space.

Analysing definitions and determinations of researchers of different historical periods, authors came to the conclusion, that the strategic and modern aim of our state consists of maintenance of borders and sovereignty and in further integration to the European and евроатлантическим structures.

Exactly the included of Ukraine in the European union will be a guarantee for the construction of the legal state and claim of national independence.

Keywords: the European states, scientific nотениiar, strategy of education, geopolitical space, legal state.

DOI: https://doi.org/10.31392/NZ-npu-144.2019.17

УДК 37.091.33:78-053.6

Пань Цяньї

\title{
МЕТОДИ ДІАГНОСТИКИ ВИХІДНОГО РІВНЯ КРЕАТИВНОСТІ УЧНІВ-ПІДЛІТКІВ У НАВЧАЛЬНО-МУЗИЧНІЙ ДІЯЛЬНОСТІ
}

В статті розглядається методика діагностики початкового рівня розвитку креативності учнів підлітків у навчально-музичній діяльності. У констатувальному експерименті було використані методи спостережкення, анкетування і тестування, метод створення підлітками особистих творчих продуктів. Автор статті пропонує методи діагностики, ще містять ситуаиії реального вибору; ситуаиії вибору навчальних завдань різного рівня; ситуаиії вибору за певними критеріями; ситуації вибору навчальної мети, яка диференціюється за ступенем спрямованості; ситуаиії вибору за мотиваиією досягнення мети. Простежено зв 'язок між розвитком креативних якостей особистості учнів підліткового віку і ситуачією вибору в навчально-музичній діяльності. Зроблено висновок, що більшість респондентів - підлітків $(52,6 \%)$ мають низький і нижче середнього рівні розвитку креативних особистісних якостей і характеризуються неприйняттям вибору в нестандартній ситуайї або пасивним до нього ставленням. 
Ключові слова: діагностика, спостереження, анкетування, тестування, продуктивний метод, ситуації вибору, креативність, навчально-музична діяльність, учні підліткового віку.

Креативне мислення $є$ сприятливим інтегруючим чинником с оціалізації підлітка, оскільки соціальна діяльність учня підліткового віку $є$ вирішальновизначальною під час його соціального дорослішання, і в своїй основі має творчий характер. Проблему розвитку креативності вивчали вітчизняні та зарубіжні вчені (Л. Божович, Л. Виготський, Н. Вишнякова, Л. Дерев'яна, Дж. Гілфорд, Д. Ельконін, О. Каплуновська, Г. Костюк, К. Крутій, Н. Кузьміна,
А. Кроник, Н. Лейтес,
А. Леонтьєв,
Н. Логінова,
Т. Любарт,
В. Моляко, В. Павленко, Р. Павлюк, К. Платонов, Я. Пономарьов, Н. Посталюк, О. Ребрій, Дж. Рензуллі, С. Рибалко, С. Рубінштейн, С. Сисоєва, В. Сластьонін, Р. Стернберг, Б. Теплов, Е. Торренс, Х. Трік, О. Хамм, Ф. Шеллінг та ін.). В роботах вчених акцентується увага на пошуку засобів розвитку креативності особистості і методів організації її творчої діяльності, розглядаються питання розвитку креативних здібностей у навчальній діяльності.

Застосування проблемних ситуацій у творчій діяльності учнів розкривається в роботах Г. Балла, І. Лернера, М. Матюшкина, М. Махмутова, М. Скаткина, Т. Шамової. Однак, проблему розвитку креативних якостей підлітків у навчально-музичній діяльності засобами ситуацій вибору не було розглянуто в науковій літературі.

Мета статті - висвітлення методики діагностики креативності учнів підліткового віку в навчально-музичній діяльності.

Реалізація моделі процесу розвитку креативності учнів підліткового віку на основі використання ситуації вибору в навчально-музичній діяльності здійснювалася поетапно 3 метою виявлення особливостей розвитку креативності, перевірки розробленої програми та з'ясування шляхів удосконалення досліджуваного процесу. Дослідно-експериментальна робота проводилася В три етапи: констатувального, фрормувального та узагальнюючого.

Констатувальний етап включав в себе: аналіз креативних якостей особистості підлітків, і ступінь їх прояву у навчально-музичній діяльності, вивчення стану практики розвитку креативності школярів підліткового віку через використання ситуації вибору в навчально-музичній діяльності, вивчення і аналіз позитивного досвіду з проблеми дослідження, обгрунтування методики дослідження, організацію та проведення констатувального експерименту. В рамках дослідження було задіяно 376 учнів підліткового віку загальноосвітніх шкіл України.

Розроблені критерії та показники розвитку креативності виступають в якості алгоритму діагностики рівня креативності учнів підліткового віку, дозволяючи судити про ступінь розвиненості всього комплексу особистісних креативних якостей, оскільки обрані показники в рівній мірі представляють мотиваційно-цільову, когнітивну, діяльнісну і рефлексивну сфеери особистості.

У дослідженні активно використовувався метод педагогічного спостереження, за допомогою якого фріксувалися фракти: вчинки і судження школярів і ситуації з їх участю в умовах навчально-музичної діяльності. При 
використанні методу спостереження за навчально-музичною діяльністю учнів на даному етапі виявлено типові недоліки в навчанні різних видів цієї діяльності, що вимагають від суб'єктів навчання прояви креативних якостей особистості, зокрема: недостатньо-точний словниковий запас, невміння грамотно, логічно передати інформацію; мало емоційне виконання музичних творів; небажання самостійності вибору навчального завдання, уникнення відповідальності за прийняття рішення, відсутність потреби створення нового творчого продукту. Це вказувало на недостатність розвиненості таких креативних якостей як: ініціативність, цілеспрямованість, винахідливість, незалежність, самостійність, схильність до ризику, готовність до відповідального вибору, сприйнятливість до нових ідей і знань, творчого ставлення до навчально-музичної діяльності тощо.

В результаті спостереження вдалося встановити, що всі учні-підлітки показали наявність креативності як особистісної якості, що виражена в проявах фантазії, здатності бачити очевидні протиріччя і проблеми в навчальномузичній діяльності, допитливості, сміливості, здатності до асоціативних зв'язків. Однак, рівень креативності у більшості був нижче середнього рівня.

Для вивчення креативних якостей особистості школярів підліткового віку був використаний тест “Творчі здібності” Дж. Кінчера [3, с. 140-143],

Із зібраних даних з'ясувалося, що свій показник творчого потенціалу респонденти визначили як; “Потенціал дуже великий” - 6,2\%, "Ви творча особистість" - 27,9\%, "Ви не гірше більшості" - 37,2\%, "Ви не настільки творча особистість, як більшість" - 21,7\%, "Вам слід відвідувати гуртки з творчою спрямованістю” - 6,2\%. Те, що випробовувані високо оцінили рівень творчого потенціалу, свідчило про неадекватність їх самооцінки.

При діагностиці початкового рівня сформованості креативних якостей, виділених в числі інших якостей автором - творчого мислення, допитливості, оригінальності, уяви, інтуїції, емоційності (емпатії), почуття гумору, був використаний опитувальник Н.Вишнякової “Креативність” [1].

Учням-підліткам пропонувалося самостійно оцінити названі особистісні креативні якості за 80 питаннями, відповідаючи “так” або “ні”. При обробці результатів індекси показників креативності визначалися підсумовуванням отриманих балів. Якщо відповідь учня на питання збігалася з ключем відповіді, то він отримував один бал з даного індексового показника. Було побудовано психологічні профрілі креативності “Я - реальний” і “Я - ідеальний”. У профрілі “Я - реальний” у $36 \%$ респондентів спостерігалося переважання якостей свідомої сорери психіки - творчого мислення, допитливості, творчого ставлення до навчальної діяльності. Якості, які стосуються підсвідомої психічної сорери уява, інтуїція, емоційність, емпатія - мали показник у 42\%. Якості, які $\epsilon$ перехідними - оригінальність і почуття гумору - спостерігалися у 12\%. При побудові профілів “Я - ідеальний” у більшості підлітків (78\%) спостерігалося прагнення до представлення своєї особистості як гармонійно розвиненої і здатної до творчості, на що вказував високий ступінь рельєфності побудованих профрілів. Лише у 6\% респондентів профіль став менш 
рельєфним, що пов'язано з суб'єктивними уявленнями школярів щодо своїх креативних якостей, або з заниженою їх самооцінкою.

Учням-підліткам також було запропоновано чотири види різних за ступенем самостійності вибору навчальних завдань: вибір музичного матеріалу, письмова інструкція, усна анотація, виконавська частина.

Самостійний вибір форми презентаціі музичного матеріалу: розбір тексту, вибір виконавських засобів, партнера, інтерпретації тощо. Частково самостійний пошук з консультацією вчителя частково самостійна анотація (консультація вчителя.) Несамостійний пошук (вибір вчителя) несамостійна письмова анотація (вчитель знаходить матеріал, і пропонує фрорму анотації) не самостійний (вчитель заздалегідь готує текст, визначає форму презентації, репетирує виступ з учнем). Підготовлена не самостійно (вчитель бере активну участь в розборі тексту, виборі виконавських прийомів, інтерпретаціі).

В першому завданні - самостійний пошук і вибір музичного матеріалу 56\% учнів-підлітків вибрали варіант з частково самостійним пошуком, 48\% вважали за краще несамостійний вибір, і лише 6,0\% - здійснили самостійний пошук. Друге завдання дозволило виявити ступінь самостійності вибору в письмовій анотації, що вказувало на наявність уміння визначити проблему, інтерес учасників до отримання нової інформаціі, самостійного добування знань, розвиненості уяви і уміння письмово викладати матеріал: самостійний варіант - 3,1\%, частково самостійний - 49\%, несамостійний - 38\%. Третє завдання дозволило визначити готовність учнів-підлітків до вибору навчального завдання, їх самостійність в процесі його реалізації, наявність особистого творчого продукту, створеного на основі вільного вибору засобів. Четверте завдання - виконавська частина - було підсумковим в серії представлених навчальних завдань, передбачуваним результатом яких могла стати актуалізація інтересу до музичної діяльності через самостійний вибір навчального завдання, націленість на створення особистого творчого продукту. Самостійність виявили 15\% респондентів, частково самостійний варіант представили 24\%, решта - 61\% віддали перевагу підготовки разом з вчителем.

Фактичний результат "пробного тесту" показав наступне: велика інертність досліджуваних до здійснення процедури самостійного вибору, рівень креативності в основному нижче середнього, але даний імпульс до розвитку процесу, помітний прояв інтересу до незвичайних форм презентації музичного та інформаційного матеріалу, що відрізняються новизною і оригінальністю, самостійний вибір школярами навчальних завдань одночасно і ускладнює процес і залучає до нього можливостями творчого пошуку, самостійного прийняття рішень в нестандартних ситуаціях, що виникають в процесі роботи. Негативна реакція на установку "сам прийняв рішення - сам і відповім за результат" пов'язана з небажанням нести відповідальність за наслідки власного вибору, звідси і уникнення нестандартних ситуацій, що можна розцінювати як прояв конформізму, наявність якостей особистості - антиподів креативних.

Учням була надана можливість спільного обговорення результатів в формі дискусії, спрямованої на виявлення показників рефлексивного критерію 
розвитку креативності учнів: вміння аналізувати результат своєї діяльності, прояв варіативності в оцінці результатів спільної діяльності, вміння прогнозувати наслідки вибору, перетворити ситуацію. У дискусіі в процесі навчальної рефлексії учні виявили вміння відстоювати свою точку зору, здатність побачити нове у звичній діяльності, самостійність, відсутність категоричності в судженнях, незалежність думок і оцінок, винахідливість, почуття гумору, впевненість при невизначеності, сміливість, вразливість, готовність до ризику, здатність аналізувати, гнучкість, критичність.

В ході дискусії було відзначено: невміння аналізувати результат - низький рівень показали 12,4\% підлітків. Переважання слабо вираженої аналітичної навички - рівень нижче середнього, властивий 27,9\% учням, Нестійке вміння середній рівень, показали 40,3\%; 15,5\% респондентів відповідали рівню вище середнього - проявляли стійке вміння до самостійного аналізу, яскраво виражене вміння аналізувати результат своєї діяльності, що відповідає високому рівню розвиненості креативної якості, виявили 3,1\% підлітків.

Учням-підліткам було також запропоновано відповісти на 12 питань анкети “Музичний портрет", розробленої нами, що дозволяло отримати відомості про вміння аналізувати результат своєї діяльності, ступеня прояву варіативності (гнучкості) в оцінці результатів спільної діяльності, умінні прогнозувати наслідки вибору тощо. У процесі аналізу результатів анкети було виявлено, що більшість учнів продемонстрували наявність власної думки як особистісної якості - 62\%; відсоток індиферентних відповідей склав 21\%; у $13 \%$ респондентів відповідь була взагалі відсутня. Небажання зрозуміти іншу точку зору виявили - 16\%; категоричність була присутня у 27,9\%; не яскраво виражена категоричність спостерігалася у 34\%; не категоричними виявилися лише 15,5\%; гнучкість і толерантність притаманна 6,2\% підліткам.

Отже, низький рівень вміння прогнозувати наслідки вибору, перетворити ситуацію показали $12 \%$, нижче середнього - 43,0\%; середній рівень - 34,0\%; вище середнього - 6,0\%; високий - 3,1\%.

Зауважимо, що в процесі навчальної діяльності використовувалися такі формулювання навчальних завдань, які пропонували учням співпрацю, наприклад: “Запропонуйте свій варіант ...", "Якби я склав цей твір ....", “Допоможіть знайти вихід з ситуації, що склалася ... ”,"Встановіть відповідність між ..." тощо.

Висновки. Результати констатувального експерименту дозволили зробити висновок, що більшість респондентів-підлітків (52,6\%) мають низький і нижче середнього рівні розвитку креативних особистісних якостей і характеризуються неприйняттям вибору в нестандартній ситуації або пасивним до нього ставленням. Це виражається у відсутності або в слабкому прояві інтересу до самостійного вибору в навчальній діяльності, потреби в самостійному виборі його цілі і бажання здійснювати вибір в нестандартній ситуації, намічено зв'язок між прагненням до самостійного вибору і більш інтенсивними проявами креативності.

Креативні якості в основному проявляються слабо або частково. В 
достатній мірі розвинена сфрера когнітивних особистісних якостей: вміння вибрати необхідну інформацію - бачення проблеми, вміння орієнтуватися в стилях і жанрах, оперативно реагувати на зміни в інтерпретації музичного матеріалу - сприйнятливість до нових ідей і знань, вміння продукувати безліч різноманітних асоціацій - розвиненість уяви. Переважали такі якості, як фантазія, частково виражена проблемність, допитливість, потенційна здатність до асоціативних зв'язків.

На етапі діагностики було відзначено індиферентне ставлення учнів до вибору навчального завдання, була відсутня позитивна мотивація до створення оригінального творчого продукту, що свідчило про наявність малого досвіду реалізації творчих здібностей школярів підліткового віку. У рефлексивної сфері у значної частини учнів виявлено відсутність вміння аналізувати результат своєї діяльності, переважання комфортності і категоричності суджень в оцінці результатів спільної діяльності, а також слабке володіння прогностики наслідків вибору, відсутністю потреби в перетворенні ситуації.

Отже, відзначаємо той факт, що в освітньому процесі загальноосвітнього закладу проблеми розвитку креативності учнів приділяється недостатня увага, перераховані вище негативні чинники значно ускладнюють можливість ії розвитку в навчально-музичній діяльності. Ця обставина дозволила нам виявити умови для ефективної реалізації процесу розвитку креативності школярів через ситуації вибору в навчальній діяльності.

\section{Використана література:}

1. Вишнякова Н. Ф. Креативная психопедагогика : монографія. Ч. 1. Минск, 1995. 239 с.

2. Дерев'яна Л. Креативність як складова професійної підготовки майбугніх соціальних педагогів [Електронний ресурс]. Вісник Львів. ун-ту. 2009. (Серія "Педагогіка). Вип. 25. Ч. 4. С. 168-174. Режим доступу: http://www.nbuv.gov.ua/old_jrn/natural/vlnu/Ped/2009_25-4/21_Dereviana.pdf

3. Кинчер Дж. Книга о тебе: 40 тестов-самоисследований. Санкт-Петербург : Питер Пресс, 1996. 224 с.

4. Ребрій О. В. Сучасні концепції творчості у перекладі : монографія [Електронний ресурс]. Харків : ХНУ ім. В. Н. Каразіна, 2012. 375 с. Режим доступу: http://ekhnuir.univer.kharkov.ua/bitstream/ 123456789/8879/2/monograph 2012.

5. Сисоєва С. О. Основи педагогічної творчості. Київ : Міленіум, 2006. 344 с.

$$
\text { References: }
$$

[1] Vishnyakova N. F. Kreativnaya psihopedagogika : monografiya. Ch. 1. Minsk, 1995. 239 s.

[2] Dereviana L. Kreatyvnist yak skladova profesiinoi pidhotovky maibutnikh sotsialnykh pedahohiv [Elektronnyi resurs]. Visnyk Lviv. un-tu. 2009. (Seriia "Pedahohika). Vyp. 25. Ch. 4. S. 168-174. Rezhym dostupu: http://www.nbuv.gov.ua/old_jrn/natural/vlnu/Ped/2009_25-4/21_Dereviana.pdf

[3] Kincher Dzh. Kniga o tebe: 40 testov-samoissledovanij. Sankt-Peterburg : Piter Press, 1996. $224 \mathrm{~s}$.

[4] Rebrii O. V. Suchasni kontseptsii tvorchosti u perekladi : monohrafiia [Elektronnyi resurs]. Kharkiv : KhNU im. V. N. Karazina, 2012. 375 s. Rezhym dostupu: http://ekhnuir.univer.kharkov.ua/ bitstream/123456789/8879/2/monograph 2012.

[5] Sysoieva S. O. Osnovy pedahohichnoi tvorchosti. Kyiv : Milenium, 2006. 344 s.

ПАНЬЦяньИ. Методы диагностики выходного уровня креативности учащихсяподростков в учебно-музыкальной деятельности.

В статье рассматривается методика диагностики выходного уровня развития креативности учашихся-подростков в учебно-музыкальной деятельности. В констатируюшем эксперименте были использованы методы наблюдения, анкетирования и тестирования, метод создания подростками личньх 
творческих продуктов. Автор статьи предлагает методы диагностики, содержсащие ситуации реального выбора; ситуачии выбора учебных задач различного уровня; ситуачии выбора по определеннылм критериям; ситуации выбора учебной цฺели, дифференцирования по степени направленности; ситуации выбора по мотивации достижения цели. Прослежена связь между развитием креативных качеств личности учашихся подросткового возраста и ситуащией выбора в учебно-музыкальной деятельности. Сделан вывод, что больиинство респондентов - подростков $(52,6 \%)$ имеют низкий и ниже среднего уровни развития креативных личностных качеств и характеризуются неприятием выбора в нестандартной ситуации или пассивным к нему отношением.

Ключевые слова: диагностика, наблюдение, анкетирование, тестирование, продуктивный метод, ситуации выбора, креативность, учебно-музыкальная деятельность, учащиеся подросткового возраста.

PAN QIANYI. Output Level Diagnostic Methods creativity of students-teenagers in educationalmusical activity.

The article discusses the methodology for diagnosing the output level of creativity development of teenage students in educational and musical activities. In a stating experiment, methods of observation, questionnaires and testing, a method of creating personal creative products by adolescents were used. The author of the article offers diagnostic methods containing situations of real choice; situations of choice of educational tasks at various levels; selection situations according to certain criteria; situations of choosing an educational goal, differentiation according to the degree of orientation; situations of choice for motivation to achieve the goal. The connection between the development of creative personality traits of teenage students and the situation of choice in educational and musical activity is traced. It is concluded that the majority of teenage respondents (52.6\%) have low and below average levels of development of creative personal qualities and are characterized by a rejection of choice in a nonstandard situation or a passive attitude towards it.

Keywords: diagnostics, observation, questionnaires, testing, productive method, situations of choice, creativity, educational and musical activity, teenage students.

DOI: https://doi.org/10.31392/NZ-npu-144.2019.18

УДК 373.5.091

Позняк А. В.

\section{ОРГАНИЗАЦИОННО-ПЕДАГОГИЧЕСКИЕ УСЛОВИЯ ПЕДАГОГИЧЕСКОЙ ПРОФИЛИЗАЦИИ ОБРАЗОВАТЕЛЬНОГО ПРОЦЕССА В УЧРЕЖДЕНИЯХ ОБЩЕГО СРЕДНЕГО ОБРАЗОВАНИЯ}

В статье обосновывается актуальность педагогической профилизачии в учреждениях общего среднего образования в современных сочиокультурных условиях. Автор обращается к опыту организации деятельности педагогических классов в Республике Беларусь в условиях введения в 2015 году профильного обучения в стариих классах. Обосновываются основные организаиионно-педагогические условия эффективной педагогической профилизации. Они раскрываются через нормативное правовое, учебнометодическое, организачионно-технологическое и ресурсно-информационное обеспечение. Дана краткая характеристика каюдого из условий. На основе результатов многолетнего мониторинга делается вывод об эффективности применения комплекса рассмотренных условий.

Ключевые слова: профилизаиия, педагогическая профилизация, педагог, педагогические классы, непрерывное педагогическое образование, организачионно-педагогические условия.

(стаття подана мовою орихіналу) 